\title{
MANAGING MARKETING REPORT ON L'ORÉAL GROUP
}

VERONIKA ŠÍROVÁ 
L'Oréal Group, the largest cosmetics and beauty corporation in the world (Rooney, 2014), offers beauty product innovation to women and men with regards to their diversity through its large portfolio brand that is present in 130 countries (L'Oréal, 2015b). According to Abnett (2015), L'Oréal has strong growth. The annual report (L'Oréal, 2015b) reveals that in 2014, the operating profit increased to 3,891 million Euros from 2013, and sales reached 22.53 billion Euros from sales, a 3.7\% increase from the year before. One could conclude these figures are of L'Oréal's benefit, as according to The Statistics Portal (2015), the global cosmetics market has grown at a slower rate since 2011 and 2012 (Figure 1). This might have impacted the competition where Avon's revenue dropped as well as Procter $\Theta$ Gamble's beauty operating division sales (Abnett, 2015).

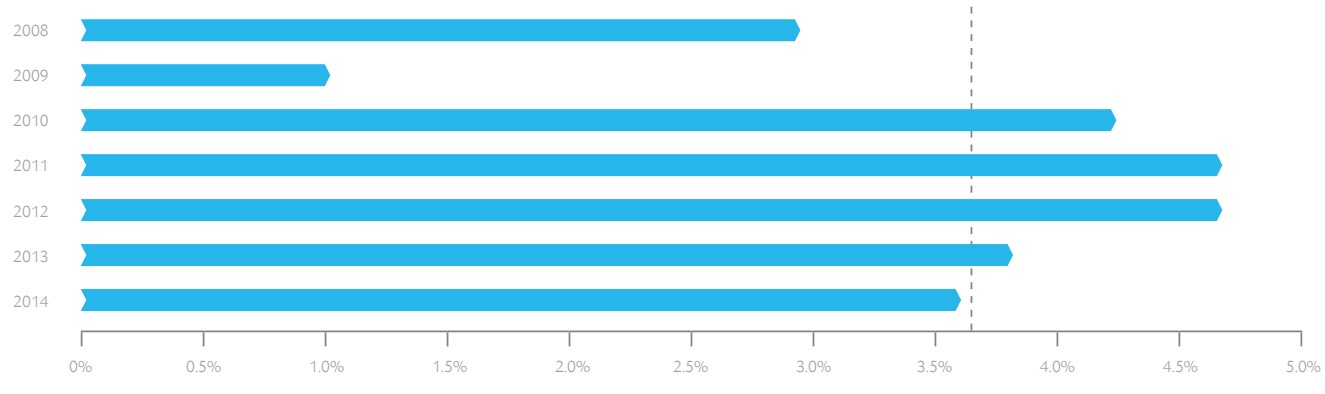

Figure 1: Annual growth of the global cosmetics industry from 2008 to 2014

Therefore, as stated by The Statistics Portal (2015) in the next few years cosmetic companies will attract and keep consumers by emphasising on product innovation. Hong and Doz (2013) however state that products, services, and business models need to be adapted to local consumers when serving both nationally and regionally. This further leads to a complex comprehension of marketing, which according to Kotler and Armstrong (2010, p. 28), is "managing profitable customer relationships" with the key goal to attract new customers, ensure a value for them, and keep the current clients by bringing satisfaction.

This is especially crucial when it comes to driving L'Oréal's "universalisation"strategy, which means globalisation representing differences (L'Oréal, 2015a), and fulfilling the organisation's aim of captivating 1 billion new clients by 2020 as mentioned by Masidlover and Burkitt (2014). Therefore, the purpose of the report is to critically assess L'Oréal Group's current marketing and how it is going to support L'Oréal's aim in winning 1 billion new customers. By utilising various theoretical models and academic sources, this critical report focusing on the application and analysis of L'Oréal's marketing, assesses the current marketing strategy, digital marketing, brand, and the pursued relationship marketing strategies of the corporation, all of these crucial components which could support L'Oréal's goal. 
The first chapter discusses L'Oréal's current marketing strategy by looking at its core marketing strategy, integrated marketing communication, and strategic marketing.

\subsection{CORE MARKETING STRATEGY: STP-D}

To create a marketing strategy, marketers must identify what customers the organisation will serve and how it will be done. According to Cant et al. (2006, pp. 103-104), the STP-D process helps companies to identify these aspects, including customer selection and value proposition. Considering that this process may aid the Group to develop and apply a suitable marketing mix, one could assume that this is the most appropriate set of tools to use. This supports the analysis of the Group's current marketing strategy and serves as an appropriate base for the promotion, a part of the marketing mix, discussed in 1.2.

\subsubsection{SEGMENTATION AND TARGETING}

Pride and Ferrell (2010, p. 161) define segmentation as separating a market into segments with specific needs, characteristics, and behaviour that may be targeted by distinct marketing strategies. It could be seen that L'Oréal segments its customers into various groups. Firstly, using demographical segmentation L'Oréal attracts people of different gender (women and men), age (young and older), and race (diversity) (L'Oréal, 2015b; Brassington and Pettitt, 2006, p. 423) by offering a complex product portfolio (L'Oréal, 2015b; The Statistics Portal, 2015) of 32 complementary brands among 5 divisions and 5 product lines. This way, a large number of people could find a suitable cosmetic product to fit their demands. Concerning the psychographic segmentation, the Group attracts different social classes by offering products for both the middle class (the consumer product division products) and the upper social class (L'Oréal Luxe division products). Additionally, L'Oréal attracts people of different personalities and lifestyles, which includes travel retail consumers purchasing in duty- free shops or natural cosmetics lovers (L'Oréal, 2015b). This way, customers' buying behaviour might be stimulated as clients can self-reflect in the beauty products. Regarding the behavioural segmentation, L'Oréal groups customers based on the benefits they demand from the products. For example, within the skincare business segment, these might be people seeking products for anti-aging, cleansers, moisturisers, anti-imperfections, and others. Overall, one can conclude that the use of multiple customer segmentation bases is due to the actuality that the customer target group of L'Oréal are a mix of demographic, psychographic, and behaviour segmentations.

\subsubsection{POSITIONING AND DIFFERENTIATION}

Kotler (2000, p. 32) states that positioning is the key benefit of the product that the target customers have in their mind. Concerning L'Oréal, its large brand portfolio demands a distinct positioning for each brand of the Group, which could be seen from each of the brands' positioning messages. For example, two L'Oréal's brands are competing in the same product division, where Garnier is well known for natural ingredients and strong scientific research (L'Oréal, 2015e), while Maybelline New York (L'Oréal, 2015f) stands for glamour, New York energy spirit, and innovation, could demonstrate the distinctive positioning. Therefore, L'Oréal focuses on a differentiation strategy by highly differentiating its products as a result of the many market segments. Consequently, in customers' minds the L'Oréal Group is positioned as a cosmetic leader with products of high quality, care, and effectiveness (L'Oréal, 2015b) among the large brand portfolio. As an example, Lancôme products carry the unique characteristics such as elegance, sophistication, and complementary skin care. Additionally, de Vries, van Helsdingen, and Borchert (2012, p. 107) state that positioning needs to be clear and differentiated to ensure a strong connection with customers, where also its repetition is crucial to stick in customers' minds, which was not the case for Garnier and Revlon who due to a weak positioning, failed in China (Masidlover and Burkitt, 2014). They also imply that other L'Oréal's brands targeted a niche market to obtain strongermarket positions than the mass labels. 
After the organisation's analysis, the author assumes that it uses product differentiation determining the qualities of the products with a combination of image differentiation due to the distinct positioning among brands. Overall, according to the author, the organisation should prevent any confusion of brands by positioning and differentiating clearly the brands in the wide portfolio. Marketers could manage this, for instance, by the integrated marketing communication analysed below.

\subsection{INTEGRATED MARKETING COMMUNICATION}

According to Jones (2007, p. 165), cosmetics are impulse buys, which are not items on a regular shopping list, and thus customers need to be stimulated. Doyle (2002, p. 250) suggests that impulse buys are easily switched for other products; therefore, companies should ensure for a frequent reminder promotion. That is a crucial element of company's marketing strategy as mentioned by Clow (2010).

\subsubsection{PROMOTIONAL TOOLS}

Kotler (2000, p. 106) reveals 5 primary promotional tools able to pass the message to the target customers, which company can influence, especially L'Oréal. According to Rooney (2014), in 2013 it spent almost $\$ 9$ billion on promotion. Figure 2 demonstrates that L'Oréal uses all of the tools, which could be great potential to attract different target groups; however, the analysis reveals some criticism.

According to the author, L'Oréal could enhance its promotion and fight the criticism by developing similar ads to Dove and its campaign for 'real beauty'. This could improve the reputation and image as Kharaim (2011, pp. 123-133) reports that promotion can assist with creating consumers' opinions or perceptions and products differentiation.

\subsubsection{BUYER READINESS STAGES}

As the promotional tools affect the consumers, Figure 3 displays the various stages of buyer readiness influenced greatly by advertising (Lovelock, 2010).

With regards to L'Oréal, it could be assumed that firstly through promotion and branding, customers are aware of the product's existence yet do not know anything else. In this case, L'Oreal needs to heavily advertise to enhance the product's promotion. Then, the customers know about its benefits such as the composition and price, and they might show their initial interest, and thus develop a connection. In the next stage, the customers prefer the product to other goods. This might be boosted by in-store product testing, which further assists with convincing customers of the product's purpose over other products. Finally, using discounts, in-store advice from personnel, or perhaps the product's availability, pull the customer to purchasing the cosmetics.

Similarly, Rooney (2004) stresses the importance of bringing the promotion towards clients. Therefore, L'Oréal informs customers about the product, how to use it, or perhaps how to achieve the desired look made by the makeup product. As Speichert (2014) says, L'Oréal adapts the content to various media. This helps them to ensure that the consumers are connected throughout the stages. However, a brand with intentions to keep its customers should also ensure for the benefits in the product and convince the customer via the product characteristics, not promotion only, especially if the promotion might be lacking the evidence, as was the case with the anti-age creams mentioned earlier. It could be assumed that unclear and inconsistent messages within the stages may harm sales. Therefore, based on the criticism to attract more consumers and pull them towards the product, L'Oréal could consider enhanced promotion, complying with relevant laws. 


\section{Advertising}

L'Oréal uses TV and magazine ads with the brand ambassadors and celebrities (L'Oréal Paris, 2015; Rooney, 2014), which together with TV, is the most prospective instruments for building awareness (Kotler, 2000, p. 106). However, L'Oréal's advertising is criticised for a lack of evidence for some of the anti-aging products (Rodriguez, 2012) or as Sweney (2011) reveals, some advertising campaigns with celebrities were removed because of over airbrushing. Therefore it could be stated that L'Oréal advertisement does not fully comply with the Food and Drug Administration law and the international advertising standards code.

\section{Sales Promotion}

Promotions, in-store materials, and the possibilities to test the products before in the stores (Neff, 2015), according to Doyle (2002, p. 250) work on behaviour, not only the mind as does advertising. However, as L'Oréal's retailors offer discounts and samples it might happen that they attract clients who tend to switch brands often according to deals and thus L'Oréal could lose money.

\section{Public Relations (PR)}

L'Oréal manages various PR activities, for example shareholder fairs (L'Oréal, 2015d), sponsoring various fashion shows, events including the Cannes Film Festival (Festival de Cannes, 2015; L'Oreal, 2015I), or launching competitions for hair stylists (The Argus 2015) and makeup artists (PR Newswire, 2015).

\section{Sales Force}

The beauty advisers in stores are talking directly to customers, which according to L'Oréal's employees, does not carry the potential (Howarth, 2014). Therefore, L'Oréal might be wasting resources.

\section{Direct Marketing}

L'Oréal uses the e-mail news marketing (L'Oreal, 2015k), which might be very informative, but less public. Thus it might not contribute to its aim greatly.

Figure 2: Promotional tools
Awareness 


\subsection{STRATEGIC MARKETING}

One of the most influential contributors of strategy is Porter (1998, pp. 61-80), who defines strategy as choosing to do activities differently to competitors. However, for the purpose of this report, the author uses Ansoff's Growth Matrix (1957, pp. 113-124), which enables companies to consider the future growth of the business using its existing and/or new products in existing and/or new markets and thus recognises 4 growth strategies as per Figure 4 .

\begin{tabular}{|c|c|c|}
\hline & Current Product & New Product \\
\hline 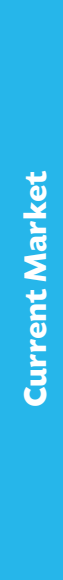 & $\begin{array}{l}\text { MARKET PENETRATION } \\
\text { Brigitte Liberman (L'Oréal, 2015b) reveals } \\
\text { that in 2014, the company further opened } \\
\text { large numbers of dermacenters worldwide. } \\
\text { Thus, one could see that L'Oréal is utilis- } \\
\text { ing its distribution channels to satisfy more } \\
\text { customers as these move across channels, } \\
\text { which could further strengthen its com- } \\
\text { petitive advantage (Rooney, 2014). }\end{array}$ & $\begin{array}{l}\text { PRODUCT DEVELOPMENT } \\
\text { L'Oréal is developing new products as well } \\
\text { as product variants, and complementary } \\
\text { products to its existing product lines in ex- } \\
\text { isting markets through continuous innova- } \\
\text { tion (L'Oréal, 2015b). This might be due to } \\
\text { the fact that Winter (2014a) mentions that } \\
\text { the selection of beauty products is increas- } \\
\text { ing to satisfy the consumers' needs, thus } \\
\text { for example, the beauty director advises } \\
\text { that companies may develop 2-3 shadows } \\
\text { darker choices for their make-up products. }\end{array}$ \\
\hline 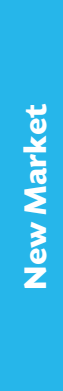 & $\begin{array}{l}\text { MARKET DEVELOPMENT } \\
\text { Premium Beauty Media (2015) publicises } \\
\text { that The Body Shop Division entered the } \\
\text { Brazilian market in } 2014 \text { for the first time, } \\
\text { and continues its expansion and will open } \\
500 \text { stores there by } 2019 \text {. }\end{array}$ & $\begin{array}{l}\text { DIVERSIFICATION } \\
\text { L'Oréal acquired Carol's Daughter, a brand } \\
\text { mixing hair care for multicultural women } \\
\text { (Winter, 2014a). However, in the future, the } \\
\text { Group might not easily establish it, as creating } \\
\text { a new product in a new country is highly risky } \\
\text { and costly especially when the portfolio aug- } \\
\text { ments as Doyle (1989, pp. 77-95) mentions. }\end{array}$ \\
\hline
\end{tabular}

Figure 4: Table of Ansoff's Growth Matrix, adapted from Ansoff (1957, pp. 113-124)

From the analysis above, the author can conclude that clearly there are various opportunities for the Group to accomplish significant growth, and thus to obtain 1 billion new customers by adopting market penetration, product development, or market development strategy. Yet, to choose, according to Kumar (2010, p. 176), the least risky way, L'Oréal might consider market penetration. According to Hill and Jones (2010, p. 197), market penetration can be achieved through heavy publicity and product differentiation. Further, this would increase L'Oréal's market share, avoid high expanses and risks, and eventually bring higher revenues. 
The following chapter inspects the extent L'Oréal utilises digital marketing and highlights the benefits for companies as it could be assumed that the trend of TV and print promotion is diminishing, while digital marketing is developing rapidly. As Ryan (2014, p. 12) mentions, digital marketing is not about understanding the technology, instead one must understand the people and their use of technology to build lasting and equally fulfilling relationships. Therefore, digital marketing provides the ability to target specific segments using the appropriate tool and message.

\section{For L'Oréal, digital marketing is a relatively new area, yet it has realised that digitalisation is a crucial aspect in its success. Consequently, in 2014 it increased its spending on digital media by $15.7 \%$ from 2013.}

Through its approach towards digital marketing based on adaptation of its innovative ethos, multi-brand, and multi-channel, it aims to connect with clients through emotions, engagement, and experiences (L'Oréal, 2015b). Figure 5 represents the digital marketing tools that L'Oréal employs, whose emphases depends on the nature of business (Ryan, 2014, p. 22).

Overall, one could assume that the set of digital marketing tools brings various benefits. For the website and e-mail marketing, these are reaching the targeted customer segments and informing them about the organisation's performance and news, which may lead to increased sales. Further, social media brings benefits like building a platform for sharing news, accessing data by receiving opinions, and staying connected with customers. While its mobile applications carry benefits such as creating noise, interacting with customers, and cosmetics advertisement.

Additionally, to the various benefits of digital marketing for companies, McKinsey er Company (2012) claim that it is justified that digital marketing in general has on average 6 times greater return on investment than TV advertisement.

\begin{tabular}{|l|l|}
\hline L'Oréal Official Website & E-mail Marketing \\
\hline Social Media & Mobile Marketing \\
\hline
\end{tabular}

Figure 5: Digital marketing

\subsection{COMBINATION OF MEDIA}

However, it may be assumed that not everyone has easy access to technology, for instance, elderly people. Also, the Internet might be limited by speed or accessibility (for example, proxy restrictions in China). Henceforth, if L'Oréal employs a digital marketing only, it is likely to be missing on some customer segments. For this reason, and because it might be hard when its products are not entirely online, the Group does not completely switch to digital marketing. Instead, it uses a mix of digital and promotional tools to follow both the younger people's trend of digitalisation and to keep the middle aged and elderly customers, who might prefer the more formal and traditional printed promotion instead. This way brand awareness is maintained among the wide customer portfolio. 


\subsection{ADAPTING TO THE TREND}

As one could strongly believe that younger consumers of cosmetics do seek trends and advice on the Internet, the Group is increasing its social media (Facebook, Twitter, YouTube, Instagram), which allows customers to stay updated, informed about the news, and raise their viewpoints. Moreover, the beauty bloggers that L'Oréal works with (Neff, 2013) try, evaluate, and share the Group's cosmetics with their followers. These both contribute to the brand awareness among the younger ones. Correspondingly, new mobile applications enable people to try products and see themselves in real time without wearing them (Winter, 2014b), match nail colour with their outfits (Howarth, 2014), or watch online diagnoses, advice, and video tutorials (L'Oréal, 2015b). Thus, customers are entertained and educated (Howarth, 2014). However, respecting the competition, Clinique's digital marketing allows clients to assess their own skin type to choose suitable products (Kotler, 2000, pp. 216-217). Therefore, the author may suggest L'Oréal to consider, as an additional development to the mobile applications, a hair app giving customers the ability to see how the hair colour suits them before purchasing it. Moreover, for those preferring the digital world, the official website is accessible in 22 languages for 35 countries (L'Oréal, 2015c), making the information available to consumers all over the world. At the same time, the Group maintains its traditional promotional tools such as TV ads, print ads, and billboards as complementary strategies to the digital marketing. This way L'Oréal does not lose the rest of its target group as it represents a constant stream of revenue.

All things considered, it could be seen that L'Oréal puts a significant emphasis on digital marketing, as currently it belongs to one of its main approaches (L'Oréal, 2015b), which may represent numerous opportunities for addressing both customers and other stakeholders. Also its website, social media, and mobile apps are largely utilised owning to the significance and benefits to the organisation. Overall, it could be recognised that continuous enhancement and expansion of L'Oréal's digital media could enjoy the benefits of digital marketing, but only with the support of TV and printed advertising it could contribute to its aim.

\section{L'ORÉAL BRAND}

The third chapter justifies the significance of the brand L'Oreal for the organisation's success that could be analysed using the brand system explained by Kapferer (2012) as shown in Figure 6. Later, the brand's value creation for customers is analysed too.

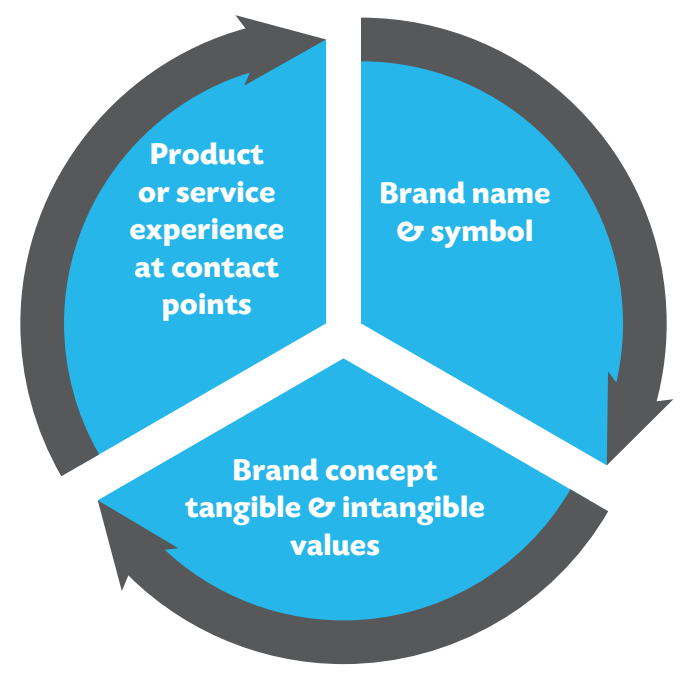

Figure 6: The brand system 


\subsection{BRAND NAME AND SYMBOL}

According to Rooney (2014), Forbes rated L'Oréal Group 28th for the world's most valuable brand, which introduces various individual brand names all possessing individual brand elements (L'Oréal Paris, The Body Shop, Vichy... ), and thus multibranding as well as a strong corporate brand could be seen. One could assume that very valuable brands possess high brand equity, which is defined as a set of associations and customer behaviour ensuring for greater sales than it could exclusive of the brand name (Kapferer, 2012, p. 13). To enhance its brand equity, L'Oréal uses its brand elements. To demonstrate, it could be seen that the corporate brand name, L'Oréal, uses a steady set of colours, the black logo, which according to the psychology associates the brand with exclusivity and glamour (Stanger, 2012). Additionally, by the globalised slogan, because you're worth it (L'Oréal, 2015g), people are able to directly recognise the brand all around the world. This contributes towards the brand's global positioning. Also Hagtvedt and Patrick (2008, pp. 379-389) prove in a form of a slogan brand it is encouraging imagination. In fact for L'Oréal's clients, it symbolises a promise, praise, and personal connection. To point out, the slogan encourages people to buy cosmetics and to cherish their looks.

\subsection{PRODUCT OR SERVICE EXPERIENCE AT CONTACT POINTS}

Kharaim (2011, pp. 123-133) identifies that brand personality might persuade customers to purchase or repurchase the products. However, as mentioned by various people (Frow and Payne, 2007, pp. 89-101; Atwal and Williams, 2009, pp. 338-346; Bethon et al., 2009, pp. 45-66) a brand's personality includes the experience, which may be the foremost element of the firms' marketing strategy. Thus, as revealed by Verhoef et al. (2009, pp. 32-41), the point-of-sales ambiance and personnel impact the comprehensive clients' experience and their decision-making. Critically assuming, it might be challenging for L'Oréal to develop and maintain a consistent set of colours, smells, noises, layout, and personnel characteristics in all of their brands point-of-sales, specifically because the majority of the L'Oréal's brands are competing with each other in the same stores, pharmacies, or hair salons.

\subsection{BRAND CONCEPT TANGIBLE AND INTANGIBLE VALUES}

Additionally, L'Oréal's brand is supported by an intangible brand concept delivered by tangibles, for instance, the delivery of a promise. The strong brand position might be an advantage in terms of brand extension. According to Doyle (2002, p. 174), brand extension is using a successful brand name to enter a new market or channel. As an example, according to the author, The Body Shop brand could be extended. To clarify, L'Oréal could offer a clothing line covering product items such as bathrobes, towels, and home wear made from $100 \%$ organic cotton, which could be sold by the same customer group. According to Kotler and Armstrong (2010, p. 258) this would aim add additional profits and exceed competitors; however, to prevent consumers from being confused, L'Oréal needs to ensure differentiation. Correspondingly, the ultimate benefits for companies having a strong brand seem to be the brand recognition and the customers. Thus, the customers think of the brand when seeing the visual expressions, talk about it, and choose it over the competitors' brands. Granted that, the customers bring revenues.

\subsection{CREATING VALUE FOR CUSTOMERS}

Supported by the strong brand system, the researcher has identified that L'Oréal brand creates values for customers. This way, the company sees how the cosmetics support the customer buying behaviour. As mentioned by Kapferer (2012, p. 20), the brand may reduce perceived risk. This way, L'Oréal's customers trust the brand. They are sure about the security and safety of the cosmetics; thus, the customers know what they are getting. Identically, L'Oréal creates enthusiasm, pleasure, appreciation, and stimulation for its customers, which could eventually lead to un-substitutable products. The brand also provides customers with various identities depending on the target group. For instance, the natural brand's Kiehl's customers might associate themselves with the brand's ethical activities such as supporting AIDS research or Lancôme clients feel like being part of a higher social class. Equally when exploring the intangible benefits, the brand 
provides a sense of belonging to customers, and thus people might feel good wearing the brand's make-up or perfume. Further, brand provides values for customers in terms of qualities noticed by contact (texture, packaging, smell, colour) and by experience (pleasure, reliability, younger look, for instance). Additionally, these brand values may lead to higher brand awareness, securing future sales volume, customer satisfaction, and loyalty, which could be highly relevant towards achieving L'Oréal's goal.

\section{RELATIONSHIP MARKETING STRATEGIES}

This chapter analyses L'Oréal's current relationship marketing approach while applying customer retention, customer lifetime value, customer churn, and customer loyalty. Also throughout the analysis, the advantages of such an approach are identified for both the organisation and its customers.As stated by van Raaij et al. (2003, pp. 41-58), 20\% of all the customers buy $80-90 \%$ of the production of the company. Therefore, agreeing with Moutinho and Southern (2010, p. 21), those buyers are highly valuable to the organisation, and thus a company must retain them with exceptional benefits. L'Oréal (2015d) understands that effective relationship marketing is essential for its growth; therefore, the organisation listens to customers, provides customer service, and constantly improves customer relations. To emphasise, this could be seen by engaging in various activities analysed below.

\subsection{CRM DATABASES}

Firstly, L'Oréal strengthens its customer relationship marketing strategy by pursuing agencies managing their CRM (customer relationship management) databases, which according to My Customer (2007), primarily increase customer loyalty and decreases churn. For instance, in the UK one of L'Oréal's agencies creates and runs a database which involves collecting data, designing the database, its creation, and analytical examination leading to enhanced segmentation of the market (Billings, 2003). Thus, the organisation enhances its marketing information, is aware of customer needs, and is able to sell more effectively, while for customers the CRM results in enhanced interaction with the organisation, more effective customer service to enjoy, and higher satisfaction. However, due to the wide brands portfolio, L'Oréal possesses numerous CRM systems, which one can believe that do not show an overall picture and some inconsistencies might occur. Similarly, this might result in a costly and time-consuming analysis.

\subsection{UP-SELLING AND CROSS-SELLING}

Also L'Oréal reinforces customer relationship marketing strategy by engaging in cross-selling and up-selling. To clarify, L'Oréal's beauty advisors in the points-of- sales offer additional items to the clients and thus create attention for other products, either within the same (up-selling) or different (cross-selling) product line. However, as My Customer (2007) reveals, L'Oréal might have an ineffective cross-selling due to lacking a single internal CRM and by not using the information properly. The Group then benefits by having teams of efficient salespeople contributing to establishing profitable relationships and correspondingly, customers' needs are filled by suitable products and services.

\subsection{ORDERGROOVE}

Additionally, L'Oréal uses the OrderGroove company to perform a customer relationship marketing strategy. As revealed by Chaey (2012), L'Oréal's clients can subscribe for their preferred skincare products, which then will be supplied to them regularly. OrderGroove states that by using this technology L'Oréal recognises a 2-4 growth in customer lifetime value (Chaey, 2012). This potentially decreases customer churn, thus its customers tend to stick to L'Oréal cosmetics. For L'Oréal this carries benefits of enhanced productivity by adjusting the inventory through effective targeting and at the same time it may shorten the sales cycle. As a result, the customer then benefits by the product's availability. 


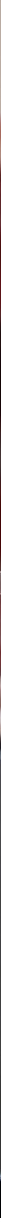

REUTERS/Charles Platiau

\subsection{LOYALTY PROGRAMMES}

According to Ergin (2005, pp. 5-16), customer loyalty is a powerful competitive benefit for a brand; thus by the loyalty programmes L'Oréal follows the customer relationship marketing strategy as well. For example, the brand Vichy organised a "100 days, 100 women" programme, which provided a diagnosis and Vichy product for 100 days (L'Oréal, 2015h). This develops tighter bonds with customers. As a benefit for the Group, loyalty programmes make customers less sensitive and thus clients pay a higher price, which leads to higher profits. In return, customers benefit by elite rewards and vouchers, which as justified by Magee (2015), L'Oréal offers through its retailers. Additionally, the Group could consider offering exclusive products, which would provide selected customers with prestige, exclusivity, and access to special products and services. As these customers would be talking about this programme, people would like to be part of it. Eventually, this could satisfy customers and keep them loyal.

\subsection{DIRECT EMAILS}

Lastly, L'Oréal sends directs emails to customers based on purchase history (Jones, 2014). However, critically assuming in a department store, L'Oréal cannot effectively gather customers' data as people share their email with the store, not the brand. Instead, L'Oréal could consider engaging customers into entering its website where they can register, and in return complete a questionnaire providing the company with feedback and customers are able to enjoy better customer service. Again, this way satisfied customers might more likely speak positively about the company and remain loyal for longer.

Overall, CRM, cross-selling and up-selling, OrderGroove, loyalty programmes, and direct emails together pursue its customer relationship marketing strategy. Yet to be able to fulfill L'Oréal's aim and potentially to satisfy and retain these customers, the Group could remove some in-company rules (as data should be shared across the company which might not be allowed) and incorporate CRM software training. Also one could see the Group manage activities separately, rather than running them all in one place. Thus, a centralised relationship strategy creating a more coherent programme could be recommended. 


\section{CONCLUSION AND RECOMMENDATIONS}

L'Oréal Group aims at offering beauty product innovation to 1 billion new women and men with regards to their diversity; therefore the purpose of the report is to critically analyse L'Oréal Group's current marketing and determine how it is going to support it.

The analysis shows that a clear positioning and differentiation, improved publicity, obeying with relevant laws, and growing further through market penetration could further strengthen the brand's multiple customer segmentation. Additionally, despite the criticism, L'Oréal significantly emphasises on digital marketing through its official website, social media, email marketing, and mobile marketing. Yet, extra development of the mobile applications could be suggested. In terms of branding, the Group's brands possess different values and elements, yet all together build a strong corporate brand equity, which could be further boosted by the overall experience and brand extension. Moreover, based on the analysis to improve the current relationship marketing strategies, L'Oréal might consider engaging customers to be part of an exclusive programme or to register through its official website; however the Group might be required to remove some in-company rules and integrate CRM software training to gain even more advantages. Additionally, a coherent centralised relationship strategy programme could be recommended.

Overall, based on the conducted analysis of its current marketing, it could be concluded that there are various aspects supporting L'Oréal's aim; however there is room for improvement in order to attract 1 billion new customers by 2020 .

\section{REFERENCES}

Abnett, K. (2015) 'Sixty-Six Shades of Skin: Tapping the Multicultural Beauty Market', The Business of Fashion, 22 April. Available at: http://www.businessoffashion.com/articles/intelligence/sixty-six-shades-skin-tapping-multiculturalbeauty-market (Accessed: 18 April 2015).

Ansoff, H.I. (1957) 'Strategies for Diversification', Harvard Business Review, Vol. 35, No.5, pp. 113-124.

Atwal, G. and Williams, A. (2009) 'Luxury Brand Marketing - The Experience is Everything!', Journal of Brand Management, 16/5 (February), pp. 338-346.

Berthon, P.R., Pitt, L.F., Parent, M. and Berthon, J.P. (2009) 'Aesthetics and Ephemerality: Observing and Preserving the Luxury Brand', California Management Review, 52/4 (Fall), pp. 45-66.

Billings, C. (2003) 'L'Oreal ramps up customer relationship strategy', Brand Republic, 26 March. Available at: http://www.brandrepublic.com/article/175087/loreal-ramps-customer-relationship- strategy\#l84rHG1cd3qpBAjS.99 (Accessed: 29 April 2015).

Brassington, F. and Pettitt, S. (2006) Principles of Marketing. 4th edn. Essex, UK: Pearson Education.

Cant, M.C., Strydom, J.W., Jooste, C.J. and du Plessis, P.J. (2006) Marketing Management. 5th edn. Cape Town, South Africa: Juta er Co. Ltd.

Chaey, C. (2012) 'How OrderGroove Brings The Subscription Model, Customer Loyalty To Big Brands', Fast Company. 6 November. Available at: http://www.fastcompany.com/3002735/how- ordergroove-brings-subscriptionmodel-customer-loyalty-big-brands (Accessed: 29 April 2015).

Clow, M. (2010) Integrated Marketing Communications. New York: Pearson Education.

de Vries, W., van Helsdingen, P., and Borcher, T. (2012) Service Marketing Management: An Introduction. Groningen: Noordhoff Uitgevers.

Doyle, P. (1989) 'Building strategic options', Journal of Marketing Management, 5(1), pp. 77-95. Doyle, P. (2002)

Marketing management and strategy. 3rd edn. Essex, UK: Pearson Education. 
Ergin, E.A. (2005) 'Brand Loyalty In The Cosmetics Industry: A Field Study On Turkish Women's Brand Loyalty Among Cosmetics Products', Journal of Business er Economics Research, May, Vol.3, No.5, pp. 5-16.

Festival de Cannes (2015) Partners. Available at: http://www.festival- cannes.com/en/about/officialPartners.html (Accessed: 20 April 2015).

Frow, P. and Payne, A. (2007) 'Towards the 'Perfect' Customer Experience', Journal of Brand Management, 15/2 (November), pp. 89-101.

Hagtvedt, H. and Patrick, V. (2008) 'Art Infusion: The Influence of Visual Art on the Perception and Evaluation of Consumer Products', Journal of Marketing Research, 45/3 (June), pp. 379-389.

Hill, C.W.L. and Jones, G.R. (2010) Strategic Management: An Integrated Approach. 9th edn. Mason, USA: South-Western, Cengage Learning.

Hong, H.J. and Doz, Y.L. (2013) 'L'Oréal Masters Multiculturalism', Harvard Business Publishing, June. Available at: https://hbr.org/2013/06/loreal-masters-multiculturalism (Accessed: 14 April 2015).

Howarth, B. (2014) 'L'Oreal goes back to the future with content marketing agenda', IDG Communications, 10 February. Available at: http://www.cmo.com.au/article/537719/__oreal_goes_back_future_content_marketing_ agenda/ (Accessed: 21 April 2015)

Jones, M. (2007) The Official CIM Coursebook. Oxford, UK: Elsevier Ltd.

Jones, S. (2014) 'Personalization is key for beauty omnichannel strategy: L'Oreal Luxe exec', Luxury Daily, 17 January. Available at: http:/ / www.luxurydaily.com/personalization-is-key-for-beauty- omnichannel-strategy-loreal-luxe-exec/ (Accessed: 17 April 2015).

Kapferer, J.N. (2012) The New Strategic Brand Management: Advanced Insights er Strategic Thinking. 5th edn. London, UK: Les Editions d'Organization.

Kharaim, H.S. (2011) 'The Influence of Brand Loyalty on Cosmetic Buying Behaviour of UAE Female Consumers', International Journal of Marketing Studies, 3, 2 (May), pp. 123-133.

Kotler, P. (2000) Kotler on Marketing: How to create, win and dominate markets. London: Simon er Schuster UK Ltd. Kotler, P. and Armstrong, G. (2010) Principles of Marketing.13th edn. New Jersey, USA: Pearson Education. Kumar, D. (2010) Enterprise Growth Strategy: Vision, Planning and Execution. Surrey: Gower Publishing Limited.

L'Oréal (2015a)A unique strategy. Available at: http://www.loreal-finance.com/eng/annual-report-2014/our-strategy (Accessed: 17 April 2015).

L'Oréal (2015b) Annual Report 2014. Paris, France: the Administration and Finance and the Image and Corporate Communication Departments.

L'Oréal (2015c) Choice of the website version. Available at: http://www.loreal.com/default.aspx (Accessed: 21 April 2015).

L'Oréal (2015d) Customer service and customer relations management. Available at: http:/ /www.loreal.com/who-you-canbe/digital/customer-service-and-customer-relations- management.aspx (Accessed: 17 April 2015).

L'Oréal (2015e) Garnier. Available at: http://www.loreal.com/brands/consumer-products- division/garnier.aspx (Accessed: 17 April 2015).

L'Oréal (2015f) Maybelline New York. Available at: http:/ /www.loreal.com/brands/consumer-products- division/ maybelline-new-york.aspx (Accessed: 17 April 2015).

L'Oréal (2015g) L'OréalParis. Available at: http://www.loreal.com/brands/consumer-products- division/loreal-paris. aspx (Accessed: 17 April 2015).

L'Oréal (2015h) Vichy supports women. Available at: http://www.loreal-finance.com/eng/annual-report-2014/activecosmetics (Accessed: 15 April 2015).

L'Oréal Paris (2015) Inside L'Oréal Paris. Available at: http://www.loreal-paris.co.uk/inside-l-oreal- paris (Accessed: 17 April 2015).

Lovelock, C.H. (2010) Services Marketing. 4th edn. New Jersey, USA: Prentice Hall.

Magee, K. (2015) 'L'Oréal calls pitch for CRM agency', CampaignLive, 22 January. Available at: http:/ /www. campaignlive.co.uk/news/1330400/ (Accessed: 17 April 2015). 
Masidlover, N. and Burkitt, L. (2014) 'L'Oréal Pulls Garnier Brand From China', The Wall Street Journal, 8 January. Available at: http://www.wsj.com/articles/SB10001424052702303848104579307972875758120 (Accessed: 17 April 2015).

McKinsey er Company (2012) 'How To Get Beyond The Social Buzz', Forbes, 7 September. Available at: http:/ /www. forbes.com/sites/mckinsey/2012/07/09/getting-beyond-the-social-buzz/ (Accessed: 17 April 2015).

Moutinho, L. and Southern G. (2010) Strategic Marketing Management. Hampshire, UK: Cengage Learning EMEA.

My Customer (2007) 'Brand management in action: L'Oreal', My Customer, 28 March. Available at: http:/ /www. mycustomer.com/topic/customer-intelligence/brand-management-action-I-oreal (Accessed: 29 April 2015).

Neff, J. (2013) 'L'Oreal Puts U.S. Digital Media Up for Review', Advertising Age, August 20. Available at: http:/ /adage. com/article/agency-news/I-oreal-puts-u-s-digital-media-review/243732/ (Accessed: 27 April 2015).

Neff, J. (2015) 'L'Oreal USA Moves to Make All Types of Ads -- Online and Off -- 'Shoppable", Advertising Age, March 12. Available at: http://adage.com/article/digital/l-oreal-usa-moves-link-kinds- ads-e-commerce/297562/ (Accessed: 17 April 2015).

Porter, M.E. (1998) 'What Is Strategy?', Harvard Business School Publishing. November - December, pp. 61-80. Available at: https://hbr.org/1996/11/what-is-strategy (Accessed: 17 April 2015).

PR Newswire (2015) 'L'Oreal Paris Unveils The Brush Contest, The Brand's First-Ever Global Online Makeup Artist Competition', PR Newswire, January 20. Available at:vhttp://www.prnewswire.com/news-releases/loreal-paris-unveilsthe-brush-contest-the-brands-first-ever- global-online-makeup-artist-competition-300022828.html (Accessed: 19 April 2015).

Premium Beauty Media (2015) 'The Body Shop plans to set up 500 stores in Brazil by 2019', Premium beauty news, January 3. Available at: http://www.premiumbeautynews.com/en/the-body- shop-plans-to-set-up-500,7677 (Accessed: 17 April 2015).

Pride, W.M. and Ferrell, O.C. (2010) Marketing. Mason, USA: South-Western Cengage Learning. Rodriguez, J.C. (2012) 'L'Oreal Anti-Aging Creams Rely on False Ads, Suit Claims', Law360, 24 September. Available at: http:/ /www.law360. com/articles/380942/l-oreal-anti-aging-creams-rely-on-false-ads-suit-claims (Accessed: 19 April 2015).

Rooney, J. (2014) 'Forbes CMO Video Interview Series: L'Oreal's Marc Speichert Revamps Marketing Inside And Out', Forbes, 4/28. Available at: http://www.forbes.com/sites/jenniferrooney/2014/04/28/forbes-cmo-video-interviewseries-loreals- marc-speichert-revamps-marketing-inside-and-out/ (Accessed: 17 April 2015).

Ryan, D. (2014) Understanding Digital Marketing. 3rd edn. London, UK: Kogan Page Limited.

Speichert, M. (2014) 'L'Oreal CMO on Transforming Brand Strategy'. Available at: http:/ /onforb.es/1rF7DZG (Accessed: 3 April 2015).

Stanger, M. (2012) 'How Brands Use The Psychology Of Color To Manipulate You', Business Insider, 29 December. Available at: http:/ / www.businessinsider.com/branding-and-the-psychology-of-color-2012-12?op=1\#ixzz3XxLpkV7Q (Accessed: 14 April 2015).

Sweney, M. (2011) 'L'Oréal's Julia Roberts and Christy Turlington ad campaigns banned', Guardian News and Media Limited, 27 July, Available at: http://www.theguardian.com/media/2011/jul/27/loreal- julia-roberts-ad-banned (Accessed: 14 April 2015).

The Argus (2015) 'Awards hope for hair salon', The Argus, 24 March. Available at: http:/ /www.theargus.co.uk/ business/11875346.Awards_hope_for_hair_salon/ (Accessed: 14 April 2015).

The Statistics Portal (2015) Annual growth of the global cosmetics market from 2004 to 2014*. Available at: http:/ / www. statista.com/statistics/297070/growth-rate-of-the-global-cosmetics-market/ (Accessed: 14 April 2015).

van Raaij, W.F. and Poiesz, T.B.C. (2003) 'Rethinking the value concept in marketing', Kitchen, P.J. (Ed.), The Future of Marketing: Critical 21st Century Perspectives, Basingstoke, Hampshire: Palgrave Macmillan, pp. 41-58.

Verhoef, P.C., Lemon, K.M., Parasuraman, A., Roggeveen, A., Tsiris, M. and Schlesinger, L.A. (2009) 'Customer Experience Creation: Determinants, Dynamics and Management Strategies', Journal of Retailing, 85/1 (March), pp. 31-41.

Winter, C. (2014a) 'L'Oréal Broadens into the Multicultural Market', Bloomberg L.P., 23 October. Available at: http:/ /www. bloomberg.com/bw/articles/2014-10-23/loreal-broadens-into-the- multicultural-market (Accessed: 14 April 2015).

Winter, C. (2014b) 'L'Oréal's Makeup Genius App: The Cosmetics Counter Goes Digital', Bloomberg L.P., 11 September. Available at: http:/ / www.bloomberg.com/bw/articles/2014-09-11/loreals-makeup- genius-app-cosmetics-countergoes-digital (Accessed: 14 April 2015). 


\section{FIGURE LIST}

FIGURE 1: The Statistics Portal (2015) Annual growth of the global cosmetics market from 2004 to 2014*. Available at: http:// www.statista.com/statistics/297070/growth-rate-of-the-global-cosmetics-market/ (Accessed: 14 April 2015)

FIGURE 2: Created by author.

FIGURE 3: Kotler, P. and Armstrong, G. (2010) Principles of Marketing.13th edn. New Jersey, USA: Pearson Education, p. 433.

FIGURE 4: Ansoff, H.I. (1957) 'Strategies for Diversification', Harvard Business Review, Vol. 35, No.5, pp. 113-124.

FIGURE 5: Created by author.

FIGURE 6: Kapferer, J.N. (2012) The New Strategic Brand Management: Advanced Insights er Strategic Thinking. 5th edn. London, UK: Les Editions d'Organization, p. 10. 
APPENDIX 1: STATISTICAL DATA

\section{Annual growth of the global cosmetics market from 2004 to 2014*}

This statistic shows the annual growth rate of the global cosmetics market from 2004 to 2014. In 2013, the global cosmetics market grew by an estimated 3.8 percent compared to the previous sales year.

\section{Show more *}

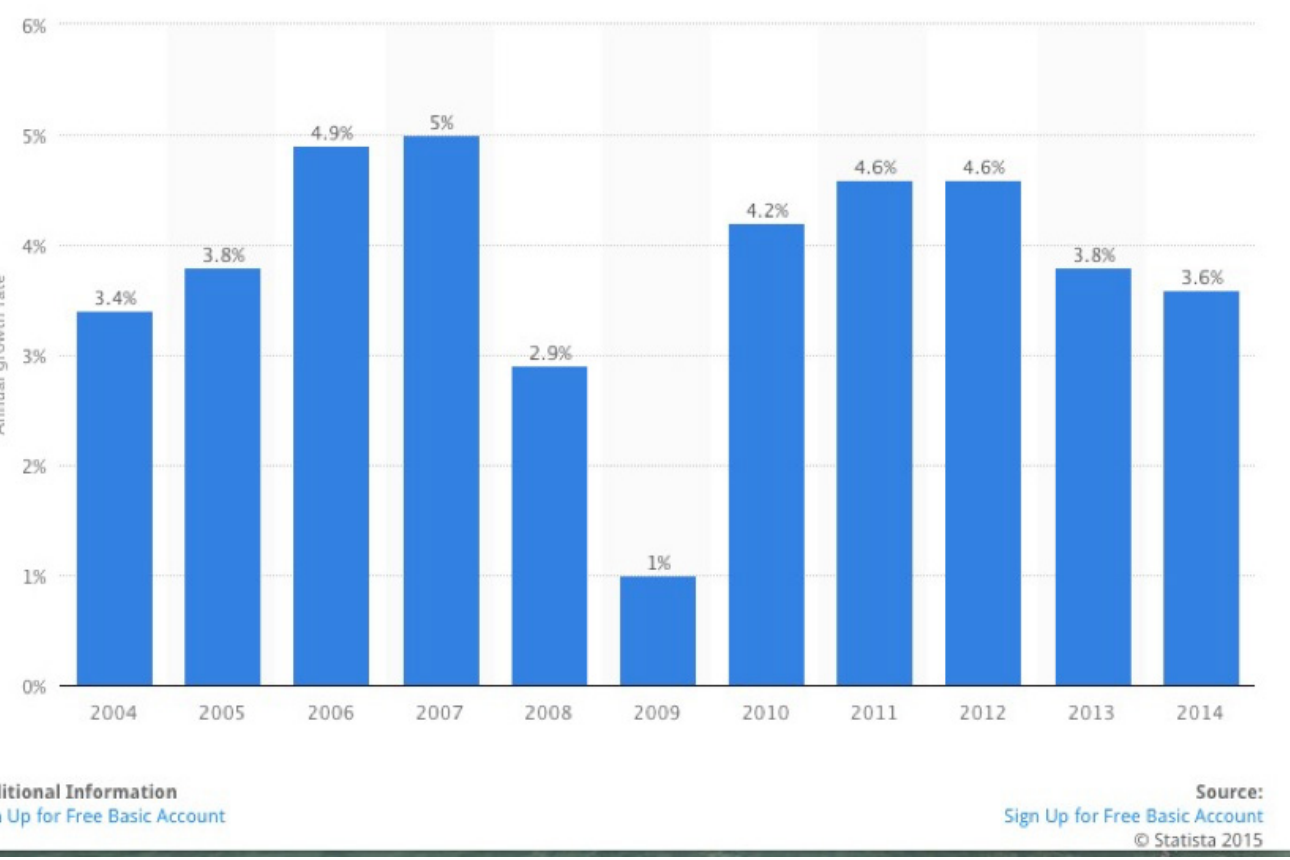

